Groothuis, P.A. and Gabriel, P.E. (2010), Positive Assortative Mating and Spouses as Complementary Factors of Production: A Theory of Labor Augmentation. Applied Economics, 42(9): 1101-1111 (April 2010). Published by Taylor \& Francis (ISSN: 0003-6846). DOI: 10.1080/00036840701721141

\title{
Positive assortative mating and spouses as complementary factors of production: a theory of labour augmentation
}

Peter Groothuis and Paul E. Gabriel

\begin{abstract}
This article develops a model of intellectual labour augmentation to explain both the marriage wage premium and educational assortative mating. We suggest that husbands and wives are complementary factors of production where a spouse's education and skills augment their partner's productivity and earnings potential. We test this proposition using data from the 2000 US Census of Population and the 2003 Current Population Survey. Our results indicate that for working couples the marriage premium for husbands and wives is directly related to the education level of their spouses - suggesting that positive assortative mating may be attributable to the labour market effects of intellectual augmentation of married households.
\end{abstract}




\section{INTRODUCTION}

The marriage premium literature finds that married men earn more than single men, even after controlling for cross-sectional differences in education, race, region or other observable characteristics (Korenman and Neumark, 1992; Daniel, 1995; Loh, 1996; Chun and Lee, 2001). In recent studies using panel data to control for unobservable characteristics, the wage premium is diminished but still present (Daniel, 1995; Cohen, 1999). An additional finding in Loh (1996) is that a wife's education enhances her husband's wage premium, although the reserve is not necessarily true. Over time, social scientists have developed numerous theories to explain the marriage wage premium for men. These paradigms range from the preferential treatment of married workers to the traditional family specialization model (i.e. men work, women run the household) (for a summary, see Reed and Hartford, 1988; Gorman, 1999).

The traditional model suggests that specialization occurs in a marriage when a husband concentrates his efforts in market work and his wife focuses primarily on home production. This pattern of specialization suggests that individuals maximize their well-being by marrying partners very different from themselves. One difficulty with the specialization model is that it is inconsistent with long-term labour market trends. In the United States, for example, the past 30 years have witnessed a significant increase in the proportion of married couples where both spouses work for pay - a trend that also applies to married couples with younger children (US Department of Labor, 1999).

The assortative mating literature, on the other hand, claims that women and men are more likely to marry spouses at the same socioeconomic level in terms of education and professional background (Mare, 1991; Quain, 1998; Suen and Lui, 1999). Mare (1991) traces this pattern from the 1930s through the 1990s in the United States. Quain (1998) finds that from 1970 to 1990 educational assortative mating existed for both marriage and cohabitation. The assortative mating literature suggests that when choosing a spouse individuals look for partners who share common productivity traits or desires for household public goods (Lam, 1988, Jepsen and Jepsen, 2002). 
A relatively unexplored area of inquiry is the question of whether both the wage premium and assortative mating might be explained by intellectual interaction between spouses that can augment each other's productivity. In other words, a spouse can provide efforts that enhance the earnings potential of their partner. This article develops a formal model that assesses the potential interactions between a person's human capital and the productivity and earnings of his or her spouse. The implications of the model, with respect to labour augmentation, are examined via an empirical analysis that explores whether husbands and wives are complementary factors of production. In particular, we investigate the extent to which a spouse's education and skills will enhance their partner's productivity and earnings potential.

\section{LITERATURE REVIEW}

Even a cursory survey of the extensive marriage premium literature yields a consistent empirical outcome: married men earn significantly more than their nonmarried counterparts, whereas the opposite appears to be true for married women. Daniel (1995) illustrates that the male marriage premium is found in different cultures, over previous centuries, and throughout a person's worklife. Estimates of this premium have ranged from Koreman and Neumark's (1991) 15\% to Bartlett and Callahan's (1984) 32\%. Chun and Lee (2001) find that the wage premium is $12.6 \%$ but ranges from $3.4 \%$ for husbands with wives who work full time to $31.4 \%$ for husbands with wives not in the labour force. Summaries of the extensive documentation of the marriage premium exist in, Kenny (1983), Bartlett and Callahan (1984) and Nakosteen and Zimmer (2001).

Although the empirical evidence of the male marriage premium is considerable, there is much less agreement on the reasons for its existence. Korenman and Neumark (1990) offer three possibilities for this difference. First, married men are more productive than unmarried workers, perhaps due to higher motivation and attachment to the labour force; second, employers display favouritism for married men over unmarried men; and third, married men possess characteristics that are more desirable in marriage and labour markets. They find that when controlling for human capital differences, hourly 
wage premiums seem to be the result of faster wage growth for married men as compared to nevermarried men. Their analysis of company personnel files indicates that married men hold higher paying jobs within the firm, but do not tend to earn more than their unmarried colleagues within the same job category. Married men also receive higher performance ratings, thus increasing their chances of promotion.

Cohen (1999), using data from the 1995-1997 Current Population Survey, examines gender, race and ethnic differences in the marriage premium as well as the cohabitation premium. He finds that marital status is more of a factor for white women than for any other demographic group. Nevermarried white women earn more than married, previously married or cohabiting white women. Additionally, never-married white women earn as much as white men. This pattern is reversed for black women with the never-married earning least. Hispanic women show no significant differences in income by marital status.

Loh (1996), building on Becker's (1975) theoretical work on the family, tests the following three propositions concerning the marriage wage premium: (1) working men with nonworking wives have a larger premium than unmarried men or men with working wives because they have greater opportunities to accumulate human capital; (2) the positive marriage premium should occur for both self-employed and salaried workers as long as they are married; and (3) currently married men 'who cohabitated with their present wife before marriage, should have a higher premium, all else being equal'.

His empirical analysis of NLSY data fails to find support for the first proposition: Men with working wives have a higher, not lower, marriage premium. Even more surprising, men earn more when their wives are more educated, even when those wives do not work outside the home. Loh suggests several reasons why this might be true. They might have fewer children but expend higher monetary outlays per child. Therefore, the wife's higher education becomes a proxy for a decreased demand for children. Loh, however, found no support for this proposition. 
The second reason Loh suggests for the positive influence of wife's education on husband's wages is that high wage men marry more educated women. Further analysis does not support this explanation either. The third reason Loh suggests for the higher wages of husbands of more educated wives is that they have better opportunities. Perhaps the presence of a better-educated spouse allows for better career decisions leading to higher wages. Loh, on further analysis, finds that the differences between wives are more important in explaining the marriage premium than the differences between the husbands themselves.

Loh also found that his prediction concerning self-employed men was not supported. In fact, unmarried self-employed men earned more than married self employed men. Similarly, Loh's prediction concerning the benefits of cohabitation on men's wages after marriage is not supported.

We are left then with the interesting finding that as a wife's education increases, so does the husband's wage. Loh states that the source of the higher wage appears to lie in unobserved heterogeneity among men in the sample. The article suggested one other possibility, namely, that more educated wives improve the resource allocation decisions of the husbands. We suggest that the primary mechanism by which a spouse enhances his or her partner's earnings potential is through intellectual labour augmentation, which is consistent with the notion of assortative mating.

In the assortative mating literature, Mare (1991) suggests that a consistent pattern of like marrying like has existed over time. Although this may be affected by the amount of time between leaving school and when the person marries, it remains a consistent finding. In fact, homogamy in mating increased from 1930 to 1980 . According to Mare, this may result from the increasing competition for high wage earning wives. The similarity in education would also predict the similarity in labour force opportunities. Thus we would expect education to be an important factor in assortative mating. Watkins and Meredith (1981), in fact, find that this is the most important variable in spouse selection.

In addition to positive assortative mating by education, others have found positive assortative mating by work status and earnings potential. Kalmijn (1994) finds that cultural assortative mating, as measured by occupational schooling (i.e. 
lawyers marring lawyers), plays a central role in the spousal selection process. Jepsen and Jepsen (2002) find that positive assortative mating exist for both opposite and same sex couples with married opposite sex couples the most alike in terms of age and education. Nakosteen and Zimmer (2001) claim that assortative mating also serves to enhance an individual's earnings potential. The results from their study suggest that spouses appear to match on the basis of unobserved earning traits, and that individuals who have a tendency to be highly productive in the labour market tend to marry similar individuals. These forms of positive assortative mating are consistent with the notion of labour augmentation.

Suen and Lui (1999) pose the question, 'how efficient is the marriage market in optimizing marital output'? Their conclusion is that it is fairly efficient. Since couples match education and wage characteristics and thus maximize their total output, augmentation in both time and intellectual interaction are likely to take place. With similar jobs and education, the ability to discuss and evaluate courses of action should be maximized. Although direct evidence of this does not exist, the higher wages of men with more educated wives certainly suggest it as a possibility - a possibility we explore in this article.

\section{THE MODEL}

In this section we develop a model of labour augmentation that is consistent with both the marriage wage premium and the assortative mating literature. Following the structure of Suen and Lui (1999), we assume that men and women who enter into marriage base their spousal selection on a joint production function, $Z_{i j}=Z\left(F_{i}, M_{j}\right.$, ), where $Z_{i j}$ is the joint production when female i marries male $j$. In an efficient market males and females sort themselves to maximize their well-being (Becker, 1973). In the traditional 'specialization-and-exchange' model the cross partial in the production function, $\partial^{2} \mathrm{Z}_{\mathrm{ij}} / \partial \mathrm{F}_{\mathrm{i}} \partial \mathrm{M}_{\mathrm{j}}$ is negative. The negative relation implies that inputs are substitutes and negative assortative mating should occur (i.e. one spouse with high education who specializes in market production and one with low education who specializes in home production). This is the traditional homemaker/bread-winner paradigm. On the other hand, the assortative mating literature suggests the opposite type of sorting: that is, highlyeducated 
individuals tend to be matched with highlyeducated spouses (Mare, 1991; Suen and Lui, 1999). If positive assortative mating is also an efficient marriage market then the cross partial, $\partial^{2} \mathrm{Z}_{\mathrm{ij}} / \partial \mathrm{F}_{\mathrm{i}} \partial \mathrm{M}_{\mathrm{j}}$ is positive. In this sorting equilibrium the positive cross partially implies that spouses are complementary factors (Suen and Lui, 1999). This implies that a husband with a high education is more productive when he marries a wife of high education and vice versa. This model also suggests that the wife's productivity rises with matched characteristics of the husband.

If this complementary relation is present, a wage premium should develop for both the husband and wife to reflect the benefits of marriage. Yet, empirically the wage premium has generally only been found for husbands. We suggest this may develop because of labour augmentation where a spouse enhances a partner's productivity by providing his or her own time and effort on the other's work. This augmentation maximizes household income but not necessarily individual income.

To address more directly the issue of labour augmentation in a positive assortative mating general equilibrium framework, our model extends Suen and Lui's (1999) efficient marriage to address how spouses may allocate their time once an efficient match has been made. In our model, a spouse enhances their partner's productivity by providing his or her own time and effort in support of the other's work. Following Daniel (1995), we hypothesize that a spouse can use their time in three ways: first, they can engage in market work; second, they can augment their spouse's productivity; and third, they can pursue leisure activities. For simplicity, we omit leisure time and focus on the choice between direct market work and augmenting a spouse's productivity using an additively separable production function. Thus the joint maximization decision can be expressed as: 


$$
\operatorname{Max} Z=z_{m}\left(t_{d m}, t_{a f}\right)+z_{f}\left(t_{d f}, t_{a m}\right)
$$

Subject to $T_{m}=t_{d m}+t_{a m}$ and $T_{f}=t_{d f}+t_{a f}$

where $z_{m}\left(t_{d n}, t_{a f}\right)$ is a husband's market output that depends upon their direct time input, $t_{d n}$ and their spouse augmentation input, $t_{a f}$. While $z_{f}\left(t_{d f}, t_{a m}\right)$ is a wife's market output that depends upon their direct time input, $t_{d f}$ and their spouse augmentation input, $t_{a m}$ and $T_{m}$ is a husband's total time and $T_{f}$ is a wife's total time to allocate to market work.

Note that the time constraint can be rearranged to $t_{a}=T-t_{d}$ for both spouses and through substitution of the time constraint in to the market output decision we can express the maximization problem as

$$
\operatorname{Max} Z=z_{m}\left(t_{d m}, T_{f}-t_{d f}\right)+z_{f}\left(t_{d f}, T_{m}-t_{d m}\right)
$$

with first order conditions:

$$
\begin{aligned}
& \left(\partial z_{m}\left(t_{d m}, T_{f}-t_{d f}\right) / \partial t_{d m} \partial z_{f}\left(t_{d f}, T_{m}-t_{d m}\right) / \partial t_{d m}=0\right. \\
& \text { and } \\
& \partial z_{f}\left(t_{d f}, T_{m}-t_{d m}\right)-\partial z_{m}\left(t_{d m}, T_{f}-t_{d f}\right) / \partial t_{d f} / \partial t_{d f} \\
& \quad=0
\end{aligned}
$$


Using men for reference, the intuition of the first order conditions (3) is that a spouse should allocate their market time to either their own production $\left(\partial z_{m}\left(t_{d m}, T_{f}-t_{d f}\right) / \partial t_{d m}\right)$, or to the augmentation of their spouse's production $\left.\left(-\partial z f_{d f}, T_{m}-t_{d m}\right) / \partial t_{d m}\right)$, until the marginal product of both are equal. In the context of labour augmentation, there are three potential outcomes of interest. The first outcome is where the wife augments her husband's market production but a husband doesn't augment his wife's market production. In terms of our model, this outcome can be expressed as:

$$
\frac{\partial z_{m}\left(t_{d m}, T_{f}-t_{d f}\right)}{\partial t_{d f}>0}
$$

and

$$
\frac{\partial z_{f}\left(t_{d f}, T_{m}-t_{d m}\right)}{\partial t_{d m}=0}
$$

This result leads to higher wages by husbands and lower wages to wives. Traditionally, this is what has been found in the literature. A second outcome is that a wife's market production is augmented by a husbands input while a wife does not augment her husband's productivity:

$$
\frac{\partial z_{m}\left(t_{d m}, T_{f}-t_{d f}\right)}{\partial t_{d f}=0}
$$

and

$$
\frac{\partial z_{f}\left(t_{d f}, T_{m}-t_{d m}\right)}{\partial t_{d m}>0}
$$

This result leads to higher wages for wives and lower wages to husbands, a result not generally found in the literature. The third possible outcome occurs when both marginal products are positive. Thus, a wife and husband augment each other's productivity:

$$
\frac{\partial z_{m}\left(t_{d m}, T_{f}-t_{d f}\right)}{\partial t_{d f}>0}
$$

and

$$
\frac{\partial z_{f}\left(t_{d f}, T_{m}-t_{d m}\right)}{\partial t_{d m}>0}
$$


In expression (7) we see that this result has an ambiguous effect on wages: a husband and a wife could both experience higher wages in marriage.1 Expression (7) is the labour augmentation outcome. The intuition of this model suggests that spouse who chooses to augment their partner's productivity can raise their partner's earnings potential and thereby create a wage premium. For example, a husband's wage premium can be interpreted as wife's payment for productivity enhancement. Examples of labour augmentation include spouses who proofread their partner's presentations, serve as sounding boards, or provide other forms of professional support.

Daniel (1995) suggests that 'just as a worker's market human capital affects her ability to perform a job, augmentation capital affects her ability to augment productivity'. If spouses are complementary factors of production, as suggested by Suen and Liu (1999), labour augmentation will develop because of positive assortative mating. Daniel (1999) conjectures that 'the ability of one spouse to augment the productivity of the other may depend upon the match between the couple's characteristics or jobs one lawyer might be better at augmenting the productivity of another lawyer'. We suggest that this type of labour augmentation capital develops due to the positive assortative mating that occurs in efficient marriage markets where the cross partials are positive.

Empirically, the earnings potential of an individual (i) can be modelled as a function of their productivity ( $\mathrm{Zi})$, which in turn is influenced by their own characteristics (Xi), and by the characteristics of their spouse (XS). This model can be expressed as, 


$$
W_{i}=Z_{i}\left[X_{i}\left(X_{S}\right)\right]
$$

where $W_{i}$ is their market wage, $Z_{i}$ is market productivity, $X_{i}$ is a set of characteristics that influence productivity, and $X_{S}$ is the matched spouse's characteristics that enhances their productivity.

Following the works of Mincer (1974) and Becker (1975) we can specify the earnings model in Equation 9 as separate human capital wage equations for males and females, modified to incorporate both the husband's and wife's characteristics. The wage equations can be written as:

$$
\begin{aligned}
& \text { Wages }_{\text {Mak }} \\
&= \beta_{0}+\beta_{1} \text { Education }_{\text {Male }}+\beta_{2} \text { Education }_{\text {Female }} \\
&+\beta_{3}\left(\text { Education }_{\text {Male }} \times \text { Education }_{\text {Female }}\right) \\
&+\beta_{4} \text { SAMEIND }+\beta_{5} \text { SAMEOCC }+X \beta+\epsilon,
\end{aligned}
$$

$$
\begin{aligned}
& \text { Wages }_{\text {Female }} \\
&= \theta_{0}+\theta_{1} \text { Education }_{\text {Female }}+\theta_{2} \text { Education }_{\text {Male }} \\
&+\theta_{3}\left(\text { Education }_{\text {Female }} \times \text { Education }_{\text {Male }}\right) \\
&+\theta_{4} \text { SAMEIND }+\theta_{5} \text { SAMEOCC }+\mathrm{X} \theta+\epsilon,
\end{aligned}
$$


where $\beta$ and $\theta$ represent coefficients to be estimated, Education measures years of schooling completed, SAMEIND is a dummy variable equal to one if both husband and wife work in the same industry and SAMEOCC is a dummy variable equal to one if both husband and wife work have the same occupation, and $\mathrm{X}$ is a vector of other personal traits that are linked statistically to earnings. ${ }^{2}$ To test for the presence of labour augmentation we can estimate the coefficients in Equations 10 and 11 and determine the partial effect of a spouse's education on a worker's earnings.

In particular, the marginal effect of another year of schooling for a husband in the household consists of two effects. First, the direct effect of the husband's education on the husband's own wage can be expressed as:

$$
\frac{\text { dWages }_{\text {Male }}}{\partial \text { Education }_{\text {Male }}}=\beta_{1}+\beta_{3} \text { Education }_{\text {Female }}
$$

where $\beta_{1}$ is the increase in the husband's wage due to the husband's increased education and $\beta_{3}$ Education $_{\text {Female }}$ is the complementary augmentation of the husband's wage through his wife's education. In our model, $\beta_{3}$ is predicted to be positive. The second effect is the indirect effect of the husband's education on his wife's wage,

$$
\frac{\partial \text { Wages }_{\mathrm{Female}}}{\text { Education }_{\mathrm{Male}}}=\theta_{2}+\theta_{3} \text { Education }_{\mathrm{Female}}
$$

where the complete marginal effect is predicted to be positive if husband and wife are complementary factors of production. In addition, the coefficients on SAMEIND and SAMEOCC are predicted to be positive in our model because both control for the specific nature of human capital.

The wife's marginal effects follow the same pattern as her husbands. Thus, the direct effect of education on her own wage is:

$$
\frac{\text { dWages }_{\text {Female }}}{\partial \text { Education }}=\theta_{1}+\theta_{3} \text { Education }_{\text {Male }}
$$

where $\theta_{3}$ Education $_{\mathrm{Malc}}$ is the enhancement due to her husband's education. The indirect effect is:

$$
\frac{\partial \text { Wages }_{\text {Male }}}{\partial \text { Education }_{\text {Female }}}=\beta_{2}+\beta_{3} \text { Education }_{\text {Male }} \text {. }
$$

where the complete effect is predicted to be positive if the husband and wife are complementary factors. 
Table 1. Variables for the human capital wage equations

\begin{tabular}{|c|c|}
\hline $\begin{array}{l}\text { Dependent variable } \\
\text { LnW: }\end{array}$ & Logarithm of weekly wage and salary income \\
\hline \multicolumn{2}{|l|}{ Independent variables $(\mathrm{X})$} \\
\hline \multicolumn{2}{|l|}{ Human capital variables: } \\
\hline EDUCATION & Years of schooling completed by respondent \\
\hline EXPER & Years of 'potential' labour market experience: (Age-EDUCATION-5) \\
\hline EXPERSQ & $(\text { EXPER })^{2}$ \\
\hline \multicolumn{2}{|l|}{ Labour augmentation variables } \\
\hline SPOUSEDUC & Years of schooling completed by respondent's spouse \\
\hline EDUCATIONXSPOUSEDUC & Interaction term between EDUCATION and SPOUSEDUC \\
\hline SAMEOCC & $\begin{array}{l}\text { Set equal to } 1 \text { if an individual is employed in the same occupational category as his/her } \\
\text { spouse, } 0 \text { otherwise }\end{array}$ \\
\hline SAMEIND & $\begin{array}{l}\text { Set equal to } 1 \text { if an individual is employed in the same industry category as his/her } \\
\text { spouse, } 0 \text { otherwise }\end{array}$ \\
\hline \multicolumn{2}{|c|}{ Demographic variables and other earnings-related traits } \\
\hline UNION & $\begin{array}{l}\text { Set equal to } 1 \text { if an individual reports that his/her workplace is covered by a collective } \\
\text { bargaining agreement, } 0 \text { otherwise (CPS sample only) }\end{array}$ \\
\hline BLACK & Set equal to 1 if an individual is black, nonHispanic, 0 otherwise \\
\hline HISPANIC & Set equal to 1 if an individual is Hispanic, 0 otherwise \\
\hline FTIME & Set equal to 1 if an individual usually works 35 or more hours per week, 0 otherwise \\
\hline NEAST & $\begin{array}{l}\text { Set equal to } 1 \text { if an individual lives in the Northeast census region, } 0 \text { otherwise (omitted } \\
\text { category from wage regressions) }\end{array}$ \\
\hline MWEST & Set equal to 1 if an individual lives in the Midwest census region, 0 otherwise \\
\hline WEST & Set equal to 1 if an individual lives in the West census region, 0 otherwise \\
\hline SOUTH & Set equal to 1 if an individual lives in the South census region, 0 otherwise \\
\hline METRO & Set equal to 1 if an individual lives in a metropolitan area, 0 otherwise \\
\hline DISAB & $\begin{array}{l}\text { Set equal to } 1 \text { if the individual reports a work-limiting disability, } 0 \text { otherwise (Census } \\
\text { sample only) }\end{array}$ \\
\hline
\end{tabular}

In our model, the marginal effects of both the husband's and wife's education suggest that spouses who are complementary factors provide another reason for positive assortative mating. Thus, positive assortative mating occurs because of productivity reasons as husbands and wives augment each other's market wages.

\section{DATA AND EMPIRICAL RESULTS}

For our empirical analysis we obtained crosssectional samples of working couples from two data sources. The first source is the $1 \%$ Public Use Microdata Sample (PUMS) of the 2000 US Census of population. Our second source is the March 2003 Annual Demographic file of the US Current Population Survey (CPS). Both the Census and CPS data provide large, representative samples of workers in the US labour market. Our samples of married couples consist of nonagricultural wage and salary workers with positive weekly earnings, who were not in the military, or enrolled in school. Given these sample criteria, we were able to construct a 
sample of 192905 married working couples from the census data, and 2775 couples from the CPS data.3

Table 2. Descriptive statistics 2000 US Census of Population (1\% public use microdata sample) \& March 2003, Current Population Survey, Annual Demographic File

\begin{tabular}{|c|c|c|c|c|}
\hline \multirow[b]{3}{*}{ Variable } & \multicolumn{4}{|c|}{ Sample means or proportions } \\
\hline & \multicolumn{2}{|c|}{ Census } & \multicolumn{2}{|c|}{ CPS } \\
\hline & Males & Females & Males & Females \\
\hline Weekly earnings (\$) & 929.03 & 586.65 & 904.79 & 607.31 \\
\hline LnW & 6.56 & 6.12 & 6.64 & 6.19 \\
\hline EDUCATION & 13.65 & 13.69 & 13.82 & 13.83 \\
\hline EXPER & 23.35 & 22.10 & 23.92 & 22.48 \\
\hline EXPERSQ & 647.58 & 584.87 & 674.41 & 606.28 \\
\hline SPOUSEDUC & 13.69 & 13.65 & 13.83 & 13.82 \\
\hline EDUCATION $\times$ SPOUSEDUC & 191.08 & & 195.21 & \\
\hline SAMEOCC & 0.210 & & 0.211 & \\
\hline SAMEIND & 0.216 & & 0.230 & \\
\hline FULLTIME & 0.836 & 0.598 & 0.891 & 0.680 \\
\hline UNION & - & - & 0.178 & 0.127 \\
\hline BLACK & 0.078 & 0.073 & 0.100 & 0.088 \\
\hline HISPANIC & 0.075 & 0.078 & 0.110 & 0.106 \\
\hline NEAST & 0.194 & & 0.181 & \\
\hline MWEST & 0.264 & & 0.261 & \\
\hline WEST & 0.190 & & 0.206 & \\
\hline SOUTH & 0.352 & & 0.351 & \\
\hline METRO & 0.820 & & 0.812 & \\
\hline DISAB & 0.088 & 0.079 & - & - \\
\hline $\begin{array}{l}\text { Sample size (number of } \\
\text { married couples) }\end{array}$ & 192905 & 2775 & & \\
\hline
\end{tabular}

The variables used to estimate the human capital wage models (Equations 10 and 11) are described in Table 1. In general, the independent variables are similar across both samples. Table 2 presents the descriptive statistics for working couples from the CPS and Census data. As expected, men have higher weekly earnings, more work experience and are more likely to work full-time than women. One finding consistent with the assortative mating - labour augmentation proposition is that $\sim 20 \%$ of working couples are employed in the same occupation or industry as their spouse. 4 
Table 3. Estimated wage regression coefficients (with SE) 2000 US Census of Population (1\% public use microdata sample) March 2003, Current Population Survey, Annual Demographic File dependent variable: logarithm of weekly wage and salary income

\begin{tabular}{|c|c|c|c|c|c|c|c|c|}
\hline \multirow[b]{2}{*}{ Variable } & \multicolumn{4}{|c|}{ Census } & \multicolumn{4}{|c|}{ CPS } \\
\hline & Males & & Females & & Males & & Females & \\
\hline Constant & $5.172^{* * * *}$ & $(0.026)$ & $4.852^{* * * *}$ & $(0.029)$ & $5.150^{* * * *}$ & $(0.202)$ & $5.062^{* * * *}$ & $(0.253)$ \\
\hline EDUCATION & $0.037^{* * * *}$ & $(0.002)$ & $0.043^{* * *}$ & $(0.0006)$ & $0.032^{* * * *}$ & $(0.014)$ & $0.031^{*}$ & $(0.017)$ \\
\hline EXPER & $0.044^{* * * *}$ & $(0.0006)$ & $0.016^{* * *}$ & $(0.0006)$ & $0.034^{* * * *}$ & $(0.006)$ & $0.019^{* * *}$ & $(0.005)$ \\
\hline EXPERSQ & $-0.0008^{* * *}$ & $(0.00001)$ & $-0.0003^{* * * *}$ & $(0.00001)$ & $-0.0007^{* * *}$ & $(0.0001)$ & $-0.0003^{* * * *}$ & $(0.0001)$ \\
\hline SPOUSEDUC & $-0.023^{* * *}$ & $(0.002)$ & $-0.056^{* * * *}$ & $(0.002)$ & -0.018 & $(0.014)$ & $-0.044^{* * * *}$ & $(0.016)$ \\
\hline $\begin{array}{l}\text { EDUCATION } \times \\
\text { SPOUSEDUC }\end{array}$ & $0.003^{* * * *}$ & $(0.0001)$ & $0.005^{* * *}$ & $(0.0001)$ & $0.003^{* * *}$ & $(0.001)$ & $0.003^{* * *}$ & $(0.001)$ \\
\hline SAMEOCC & $-0.012^{* * *}$ & $(0.003)$ & $0.075^{* * * *}$ & $(0.004)$ & $0.048^{*}$ & $(0.026)$ & 0.041 & $(0.029)$ \\
\hline SAMEIND & $-0.035^{* * *}$ & $(0.003)$ & $0.070^{* * * *}$ & $(0.004)$ & $-0.073^{* * * *}$ & $(0.024)$ & $0.107^{* * * *}$ & $(0.027)$ \\
\hline$R^{2}$ (adjusted) & 0.221 & & 0.277 & & 0.249 & & 0.334 & \\
\hline
\end{tabular}

Notes: *** Significant at the $1 \%$ level; ** Significant at the $5 \%$ level; * Significant at the $10 \%$ level.

Table 4. Marginal effect of husband's education on earnings by wife's level of education

\begin{tabular}{llllll}
\hline & \multicolumn{2}{c}{ Census } & & CPS \\
\cline { 2 - 3 } \cline { 5 - 6 } Wife's level of education & Wife's wages & Husband's wages & & Wife's wages & Husband's wages \\
\hline 8 & -0.0195 & 0.0625 & -.0192 & 0.0549 \\
9 & -0.0148 & 0.0659 & -.0160 & 0.0577 \\
10 & -0.0101 & 0.0691 & -.0129 & 0.0604 \\
11 & -0.0054 & 0.0723 & -.0097 & 0.0632 \\
12 & -0.0008 & 0.0756 & -.0065 & 0.0661 \\
13 & 0.0039 & 0.0789 & -.0034 & 0.0689 \\
14 & 0.0086 & 0.0822 & -.0002 & 0.0717 \\
15 & 0.0133 & 0.0854 & 0.0030 & 0.0745 \\
16 & 0.0179 & 0.0887 & 0.0061 & 0.0773 \\
17 & 0.0227 & 0.0919 & 0.0093 & 0.0801 \\
18 & 0.0273 & 0.0952 & 0.0125 & 0.0829 \\
19 & 0.0320 & 0.0985 & 0.0156 & 0.0857 \\
20 & 0.0367 & 0.1017 & 0.0188 & 0.0885 \\
\hline
\end{tabular}

Table 3 presents the estimated wage regressions, by gender, for the CPS and Census samples. Columns 1 and 3 show the estimated coefficients (and SEs) for males whereas columns 2 and 4 report the results for females. In the interest of space, we report only the regression estimates for the independent variables most relevant to our test of the labour augmentation hypothesis. In general, the estimated signs of the coefficients on the independent variables are consistent with those reported elsewhere.5 The results in Table 3 indicate that there are positive, and significant, effects on earnings that are 
due to the interaction between a worker's education and the education of his or her spouse. This is consistent with the labour augmentation - assortative mating proposition. However, this result is complicated by the negative coefficient on spouse's education for men and women in both samples. Thus, we need to rely on expressions (11) and (13) above to obtain a more accurate assessment of the full nature of the interaction between spouses' education and earnings.

Table 5. Marginal effect of wife's education on earnings by husband's level of education

\begin{tabular}{|c|c|c|c|c|}
\hline \multirow{2}{*}{$\begin{array}{l}\text { Husband's level } \\
\text { of education }\end{array}$} & \multicolumn{2}{|c|}{ Census } & \multicolumn{2}{|c|}{ CPS } \\
\hline & Husband's wages & Wife's wages & Husband's wages & Wife's wages \\
\hline 8 & 0.0027 & 0.0807 & 0.0041 & 0.0565 \\
\hline 9 & 0.0061 & 0.0854 & 0.0069 & 0.0597 \\
\hline 10 & 0.0094 & 0.0900 & 0.0097 & 0.06282 \\
\hline 11 & 0.0126 & 0.0948 & 0.0125 & 0.0660 \\
\hline 12 & 0.0159 & 0.0994 & 0.0153 & 0.0692 \\
\hline 13 & 0.0192 & 0.1041 & 0.0181 & 0.0723 \\
\hline 14 & 0.0224 & 0.1088 & 0.0209 & 0.0755 \\
\hline 15 & 0.0257 & 0.1135 & 0.0237 & 0.0786 \\
\hline 16 & 0.0290 & 0.1182 & 0.0265 & 0.0818 \\
\hline 17 & 0.0322 & 0.1228 & 0.0293 & 0.0850 \\
\hline 18 & 0.0355 & 0.1275 & 0.0321 & 0.0881 \\
\hline 19 & 0.0387 & 0.1322 & 0.0349 & 0.0912 \\
\hline 20 & 0.0420 & 0.1369 & 0.0377 & 0.0944 \\
\hline
\end{tabular}

In Tables 4 and 5, we report the marginal effect of an additional year of schooling on earnings in a household by their spouse's education. In Table 4, we calculate Equations 14 and 15 for each year of schooling from 8 to 20 . We show that for a woman with low levels of education, an additional year of schooling by her husband actually lowers her wage. However, at higher levels of education there is a positive effect on her wage, ceteris paribus. In the census sample, the cross from a negative to a positive effect on wages takes place at the high school level; in the CPS, this crossover occurs essentially at the junior college level. Table 4 also shows that the husband's returns to education are enhanced by their wife's level of education going from about $6 \%$ for a husband with a wife with a $8^{\text {th }}$ grade education to about $9 \%$ with a wife with 20 years of education. 
In Table 5, we show the marginal effect of a wife's increased level of education on both the husband's and the wife's wages calculated using Equations 12 and 13. Here we find that as wives increase their education level the husband's wage is enhanced for all but the lowest level of education. The enhancement is particularly true at high levels of education with an additional year of education by a wife increasing her husband's wage by $4 \%$ when the husband has 20 years of schooling. The wife's return to her education is also enhanced by her husband's education with the returns from schooling rising from about $5 \%$ for the Census data and $4 \%$ for the CPS data when the husband's educations climbs from 8 to 20 years of schooling. The results from both Tables 4 and 5 suggest that positive assortative mating has productivity effects with both husbands and wives augmenting their returns to schooling through their spouse's level of education.

The results from Tables 4 and 5 can also be linked to the standard empirical findings regarding the marriage wage premium. For married men we see that labour augmentation occurs for all levels of schooling. This is consistent with the virtually universal finding that marriage has a positive effect on male earnings levels. On the other hand, for

women we see that the derived marriage wage benefits from labour augmentation begin to occur at approximately the sample average level of schooling. Thus, for a significant portion of females, the education level of their husbands exerts little, or even a negative, effect on earnings. This is consistent with the ambiguity of empirical findings concerning marital status and female earnings levels.

The estimated coefficients on SAMEOCC and SAMEIND provide a mixed message with respect to men with spouses employed in the same occupational or industry category. The census results indicate that men incur a penalty for having spouses in similar occupations, whereas the CPS results indicate a positive effect on wages, albeit at the margin of statistical significance. For the Census and CPS data, there appears to be a wage penalty for men with wives employed in the same industry (SAMEIND). On the other hand, women with spouses employed in the same industry or occupation have significantly higher weekly earnings than women who work in different industries or occupations from their spouses. These 
somewhat inconsistent results may be attributable to the degree of aggregation in the industry and occupation variables. An additional factor may involve the industries and occupations that are most likely to see matched spouses. For instance, over $65 \%$ of men and women who are employed in the same occupation as their spouses (SAMEOCC $1 / 41$ ) are found in the two highest-paid categories: managerial and professional workers. This appears to have a positive effect on the earnings of women, but a more ambiguous effect on the earnings of men. For married couples employed in similar industries (SAMEIND1/41), nearly two-thirds of those workers are found in three categories: manufacturing, wholesale-retail trade and educational/ health services. 6 The estimated coefficient on SAMEIND in Table 3 indicates that females rather than males receive a premium for having a spouse employed in the same industry. Overall, women appear more likely to benefit from the potential complementary effects of having a spouse employed in the same occupation or industry.

\section{CONCLUSIONS}

This article develops a theory of intellectual labour augmentation to explain both the marriage wage premium and the possibility of educational assortative mating. Intellectual labour augmentation means that individuals search for spouses who have similar characteristics in order to maximize joint household production. This labour augmentation also suggests that having spouses of similar educational backgrounds helps to create a wage premium that reflects the synergies of marriage. Our empirical analysis of earnings data for married working couples from the US Census of Population and the Current Population Survey supports the labour augmentation argument. In general, the wages of married men and women are positively influenced by the educational attainment of their spouse, although the effect is less pronounced for women than it is for men. However, the interaction effect between the education of men and women tends to increase with the level of educational attainment of both spouses. Thus, we estimate that the complementarity in spousal education is more important for highly educated couples. An additional finding is that married women enjoy a wage premium if their spouse is employed in the same industry or 
occupation. However, this result does not appear to be true for married men.

The labour augmentation between husbands and wives reported in this article is consistent with two recent labour market trends: the increase in the average level of women's educational attainment relative to men, and the significant increase in the percentage of married couples where both spouses are employed. These trends appear to conflict with the more traditional specialization model of spousal selection as proposed by Becker and others.

\section{ACKNOWLEDGEMENTS}

We would like to thank Dan Black and Rich Hill for useful comments. We would also like to thank Jana Groothuis and Susan Schmitz for useful comments and for years of augmenting our productivity.

All errors, however, remain ours.

\section{NOTES}

1. A fourth outcome is possible where the marginal product of labour augmentation is zero for both and no labour augmentation wage effect is found in a marriage.

2. We use working couples for our samples in order to concentrate on testing the labour augmentation hypothesis for both male and female wage earners. In our sample we use all observations where both partners are either working part time or full time. We do the same analysis for a subset of workers where both spouses are full time married workers, because hours worked might be an endogenous decision in the household. The empirical results, however, are similar. We report these results in Appendix 1.

3. The census aggregate occupational and industry categories were used to construct the SAMEOCC and SAMEIND variables. The occupational categories are: managerial, professional, sales, clerical, operatives, production/craft, labourers, construction/extractive and service; the industry categories are: construction/extractive, manufacturing, wholesale/retail trade, information, finance, professional services, education and health services, recreation and hospitality, other services and public administration.

4. In addition, approximately $10 \%$ of the working couples in the Census and CPS samples are employed in the same industry and occupational categories. These percentages are significantly higher than what would occur under a random matching of couples by industry or occupation.

5. The regression results reported in Table 3 have been corrected for possible sample selection bias via Heckman's (1979) technique. The selection model is based on a probit estimation of a 
labour force participation equation (either in or out of the labour force) as a function of a respondent's experience, education, disability status, and the presence of young children. The full set of empirical estimates is available from the authors upon request.

6. For the CPS sample, the distribution of men and women with spouses in the same occupational category is: managerial (18\%), professional (49\%), service (9\%), sales (7\%), clerical (9\%), operatives (1.5\%), production/craft (5.3\%), labourers $(0.3 \%)$ and construction/extractive $(0.5 \%)$. The corresponding percentages for the industry categories are: construction/extractive (1\%), manufacturing (18\%), wholesale/retail trade (16\%), information (2\%), finance (6\%), professional services (7\%), education and health services (34\%), recreation and hospitality (5\%), other services (3.5\%) and public administration (5\%). The corresponding percentages for the Census sample are similar.

\section{REFERENCES}

Bartlett, R. L. and Callahan III, C. (1984) Wage determination and marital status: another look, Industrial Relations, 23, 90-6.

Becker, G. S. (1975) Human Capital, 2nd edn, Columbia University Press, New York.

Bowlus, A. J. (1997) A search interpretation of male-female wage differentials, Journal of Labor Economics, 15, 625-57.

Cohen, P. (1999) Racial-ethnic and gender differences in returns to cohabitation and marriage: evidence from the current population survey. U.S. Bureau of the Census, Population Division Working Paper. No 35.

Cornwell, C. and Rupert, P. (1997) Unobservable individual effects, marriage and the earnings of young men, Economic Inquiry, 35, 285-94.

Chun, H. and Lee, I. (2001) Why do married men earn more: productivity or marriage selection?, Economic Inquiry, 39, 307-19.

Daniel, K. (1995) Does marriage raise the productivity of workers? The Warton School of the University of Pennsylvania Working Paper.

Gorman, E. (1999) Bringing home the bacon: marital allocation of income-earning responsibility, job shifts and men's wages, Journal of Marriage and the Family, 61, 110-22. 
Heckman, J. Sample selection bias as a specification error, Econometrica, 47, 153-62.

Jepsen, L. K and Jepson, C. A. (2002) An empirical analysis of the matching patterns of same-sex and opposite-sex couples, Demography, 39, 435-53.

Kalmijn, M. (1994) Assortative mating by cultural and economic occupational status, American Journal of Sociology, 100, 422-52.

Keith, K. and McWilliams, A. (1999) The returns to mobility and job search by gender, Industrial and Labor Relations Review, 52, 460-77.

Kenny, L. W. (1983) The accumulation of human capital during marriage by males, Economic Inquiry, 21, 223-31.

Koreman, S. and Neumark, D. (1991) Does marriage really make men more productive?, The Journal of Human

Resources, 26, 283-307.

Lam, D. (1988) Marriage markets and assortative mating with household public goods: theoretical results and empirical implications, The Journal of Human Resources, 23, 462-87.

Loh, E. S. (1996) Productivity differences and the marriage wage premium for white males, The Journal of Human Resources, 31, 566-89.

Mare, R. (1991) Five decades of educational assortative mating, American Sociological Review, 56, 15-32.

Mincer, J. (1974) Schooling, Experience and Earnings, National Bureau of Economic Research, New York.

Nakosteen, R. A. and Zimmer, M. (2001) Spouse selection and earnings: evidence of marital sorting, Economic Inquiry, 39, 201-13.

Qian, Z. (1988) Changes in assortative mating: the impact of age and education, 1970-1990, Demography, 35, 279-92.

Reed, W. R. and. Harford, K. (1988) The marriage premium and compensating wage differentials, Texas A\&M Department of Economics Working Paper. 
Suen, W. and Lui, H.-K. (1999) A direct test of the efficient marriage market hypothesis, Economic Inquiry, 37, 29-46.

United States, Department of Labor (1999) Employment characteristics of families in 1998, News Release \#USDL 99-146.

Watkins, M. and Meredith, W. (1981) Spouse similarity in newlyweds with respect to specific cognitive abilities, socioeconomic status, and education. Journal of Behavior Genetics, 11, 1-21.

\section{APPENDIX}

Table A1. Estimated wage regression coefficients (with SE) 2000 US census of population (1\% public use microdata sample) year-round, full-time workers March 2003, current population survey, annual demographic file dependent variable: logarithm of weekly wage and salary income

\begin{tabular}{|c|c|c|c|c|c|c|c|c|}
\hline \multirow[b]{2}{*}{ Variable } & \multicolumn{4}{|c|}{ Census } & \multicolumn{4}{|c|}{ CPS } \\
\hline & Males & & Females & & Males & & Females & \\
\hline Constant & $5.379 * * *$ & $(0.034)$ & $4.961^{* * *}$ & $(0.0333)$ & $5.478 * * *$ & $(0.221)$ & $4.9592^{* * *}$ & $(0.246)$ \\
\hline EDUCATION & $0.039 * * *$ & $(0.002)$ & $0.052^{* * * *}$ & $(0.0022)$ & $0.033^{* *}$ & $(0.016)$ & $0.0613^{* * *}$ & $(0.016)$ \\
\hline EXPER & $0.035^{* * *}$ & $(0.0008)$ & $0.024 * * *$ & $(0.0006)$ & $0.011^{*}$ & $(0.006)$ & $0.012^{* * *}$ & $(0.005)$ \\
\hline EXPERSQ & $-0.0006^{* * *}$ & $(0.00001)$ & $-0.0004^{* * *}$ & $(0.00001)$ & 0.0001 & $(0.0002)$ & $-0.0001^{*}$ & $(0.0001)$ \\
\hline SPOUSEDUC & $-0.019^{* * *}$ & $(0.002)$ & $-0.022^{* * *}$ & $(0.002)$ & 0.0018 & $(0.015)$ & -0.020 & $(0.015)$ \\
\hline $\begin{array}{l}\text { EDUCATIONX } \\
\text { SPOUSEDUC }\end{array}$ & $0.003^{* * *}$ & $(0.0002)$ & $0.003^{* * *}$ & $(0.0001)$ & $0.0022^{* *}$ & $(0.001)$ & $0.002^{* * *}$ & $(0.001)$ \\
\hline SAMEOCC & 0.002 & $(0.004)$ & $0.061^{* * * *}$ & $(0.004)$ & $0.034^{*}$ & $(0.036)$ & 0.026 & $(0.028)$ \\
\hline SAMEIND & $-0.018^{* * *}$ & $(0.004)$ & $0.040^{* * * *}$ & $(0.004)$ & $-0.092^{* * *}$ & $(0.027)$ & $0.066 * * *$ & $(0.026)$ \\
\hline$R^{2}$ (adjusted) & 0.223 & & 0.268 & & 0.231 & & 0.285 & \\
\hline
\end{tabular}

Notes: ${ }^{* * *}$ Significant at the $1 \%$ level; ${ }^{* *}$ Significant at the $5 \%$ level; ${ }^{*}$ Significant at the $10 \%$ level. 